\title{
Induced innovation of the German Employees' Invention Act
}

\author{
Marcus Oehlrich \\ Business Administration, Accadis University of Applied Sciences, Bad Homburg, Germany \\ E-mail: m.oehlrich@fb.accadis.com
}

\section{Introduction}

Entered into force in 1957, the German Employees' Invention Act $^{1}$ (GEIA) is a globally unique obligatory incentive system for staff in industrial research. It traces back to earlier discussions on the dogmatic contradiction between German patent law and employment contracts, which came up with the enactment of the first German patent law in 1877. In the chemical and pharmaceutical industry the compensation for employed inventors was regulated early in a collective labor agreement ${ }^{2}$ for the academically educated employees from 15th June 1920. It is nowadays nearly forgotten that the first legal arrangement for employee inventions was then made during the Nazi era, when the Reichsminister for Armament and Ammunition, Hitler's architect Albert Speer, decreed in 1942 the order on the treatment of inventions from allegiance members. ${ }^{3}$ This order provided a basis for the enactment of GEIA in 1957. This Article is concerned with the question whether GEIA is an appropriate means to spur employees to innovative behavior. Because of its historic predecessors the pharmaceutical industry is taken as an example. Furthermore, pharmaceutical research was in the past 30 years subject to significant changes quietly undermining the very foundations of the GEIA.

Up to the 1980s, the pharmaceutical industry was considered one of the most attractive business sectors. But at the latest in the 1990s, this has changed due to attempts of cost reduction in most health care systems. This attempt caused a change in the competitive environment which resulted in increased pressure on the price levels for research based drugs. This happened not only during the term of a patent but even more so after its expiration. Besides the usual competitive strengths, there have been national interventions like price, profit or budget controls and additional payments added in most countries. More and more countries urge doctors to prescribe

\footnotetext{
${ }^{1}$ Law for Employee's Invention, dated 25.07.1957, Bundesgesetzblatt I, 756.

${ }^{2}$ Reichstarifvertrag für die akademisch gebildeten Angestellten.

${ }^{3}$ Verordnung über die Behandlung von Erfindungen von Gefolgschaftsmitgliedern (RGB1. I S. 257).
} 
the cheaper generic medicine or even regulate it with e.g. in the U.S. the Drug Price Competition and Patent Restoration Act ("Hatch-Waxman-Act") or the German Aut idem-regulation. ${ }^{4}$ Since the end of the 1980 s, the attempt of cost reduction in combination with the increased (but still incomplete) competition is going to threaten the survival of each company which encounters weaknesses in research and development. In previous times, the price for a drug, which patent protection had ended, decreased only slightly in comparison with the price under patent protection. ${ }^{5}$ Nowadays, the price for economically interesting drugs is decreasing by up to $80 \%$ just a few weeks after the patent protection has ended. At the same time, the market share of the original product drops by almost $50 \% .^{6}$ Therefore, the companies' innovative ability, meaning the ability to invent new patent protected drugs, is again being focused on.

\section{The German Employees' Invention Act (GEIA)}

GEIA regulates the employee's compensation for patentable inventions and suggestions for technical improvements. The legislator intended to incite the employees' invention for the benefit of the company and the general public. ${ }^{7}$ Due to the patent, the employer may solely use the invention and competitors are prevented form the usage. This employer's right of exclusive usage is the reason for the employee's right of compensation for his invention.

GEIA is based on the contradiction between German patent law and the employment contract. ${ }^{8}$ German patent law focuses on the inventor which means that all the rights from the invention and its patent belong to the inventor. But, according to the employment contract all output emerging from paid work is property of the employer. GEIA resolves this contradiction by reallocating rights and responsibilities between both parties. It is mandatory for a researcher to give written notice to his

\footnotetext{
${ }^{4}$ In regard to the implication of the Hatch-Waxman-Act see Henry G. Grabowski and John M. Vernon, Longer Patents for Lower Imitation Barriers: The 1984 Drug Act, American Economic Review 76 (1986), 195-199. For a critical assessment see Frederic M. Scherer, Pricing, Profits, and Technological Progress in the Pharmaceutical Industry, Journal of Economic Perspectives 7 (1993), 97-115.

${ }^{5}$ Compare the empirical analysis of John Z. Lu and William S. Comanor, Strategic Pricing of New Pharmaceuticals, Review of Economics and Statistics 80 (1998), 108-117.

${ }^{6}$ To be more precise, the prices for generic products cost are app. $80 \%$ less than the monopoly price during the time of patent protection. Richard Frank and David S. Salkever, Generic Entry and the Pricing of Pharmaceuticals, Journal of Economics and Management Strategy 6 (1997), 75-90, and Henry G. Grabowski and John M. Vernon, Brand Loyalty, Entry, and Price Competition in Pharmaceuticals After the 1984 Drug Act, Journal of Law and Economics 35 (1992), 331-350, also observed that the original product became even more expensive after the start of the generic competition.

${ }^{7}$ Governmental justification for GEIA, BT-Drucks. II/1648, S. $26=$ B1.f.PMZ 1957, 323.

${ }^{8}$ For the US see Robert P. Merges, The Law and Economics of Employee Inventions, Harvard Journal of Law and Technology 13 (1999), 5-10; Barak Y. Orbach, The Law and Economics of Creativity at the Workplace, Harvard Law School, Discussion Paper No. 356, 03/2002, $43-47$.
} 
employer right away, meaning without avoidable delay, concerning all new inventions made during working hours (notice of invention, GEIA Section 5). According to GEIA, the employer is entitled but not obligated to use inventions made during working hours. In this case, he has to state clearly his intentions in written, pay an adequate sum to the researcher (GEIA Section 9, Para. 1) and bear all the costs arising from the patent application.

The consequences for a researcher in pharmaceutical $r \& d$ who has invented a patentable active ingredient during one of his projects are enormous: his right to compensation according to GEIA lasts normally 8-12 years, the net duration in which the new drug is marketed under patent protection. He will not benefit from the financial advantages of the commercialization after expiration of the patent. The guideline for the indefinite legal concept (which needs to be specified or interpreted on a case-by-case basis) of a reasonable payment for employee invention is based on the Federal Ministry of Labor and Social Affairs according to GEIA Section 11 decreed standards for the compensation of employees' inventions. ${ }^{9}$

The assessment base for the compensation is the commercial usability of the employee invention (so-called value of invention); the amount of the compensation depends on the individual characteristics of the researcher (GEIA Section 9, Para. 2), e.g. his position and duties within the company as well as his part in making the invention in the first place (so-called participation factor). To determine the value of invention for active ingredients in the pharmaceutical industry, the analogy to a license is to be used regularly: In this case, the invention value corresponds with the fee the enterprise would have paid as license fees to a third party inventor who is not employee of the company. One has to estimate the license fees which would have been agreed upon for the invention. ${ }^{10}$ The invention value is determined according to the method of license analogy by multiplying the revenues with the license rate in percent.

\section{GEIA's legal requirements and the resulting perverse incentives}

First of all, GEIA sets incentives for inventions, i.e. patentable applied research. As it will be shown, this focus for the compensation of employees' inventions leads to perverse incentives. A key insight from agency-theory is that 'what you pay is what you get'. If compensation is limited to inventions, then employees will do inventions, although the employer has also a need for basic research.

\footnotetext{
${ }^{9}$ Standards for the compensation of employee's invention in the private sector from 20.07.1959, insert of the Bundesanzeiger no. 156 from 18.08.1959.

${ }^{10}$ German Federal Court of Justice (Bundesgerichtshof), verdict from 13.11.1997, X ZR 132/95, GRUR 1998, 689 - Copolyester II.
} 


\subsection{Necessity of a legal regulation}

The empirical findings on GEIA are ambiguous. An international comparison did not show a more groundbreaking behavior of German enterprises, ${ }^{11}$ although nationwide empirical studies described the influence of GEIA or similar regulations on the patent output as significant. Especially in the U.S., considered the target country for outstanding scientists, compensations for employees' inventions are not common. ${ }^{12}$ Therefore, a long discussion has been taken place, whether GEIA is the right means to motivate employees and cause innovative behavior. The basic problems of GEIA are due to the perceptions on which the standards for calculating the value of invention are based. They deal only with the inventor's perspective and state his minimum claim against his employer. But they do not deal with the question to which extent the usage of the invention is profitable to the employer. Actually, the adequate compensation should be determined in each case individually and should also consider the invention's benefit in the future. In an agency model it has been shown that such an individual agreement is not possible from a perspective of the economic game theory. ${ }^{13}$

\subsection{Expansion of the assessment base}

According to GEIA, employee's invention compensation has empirically proven to be a significantly determining factor for the patent output. ${ }^{14}$ But due to the restriction to patents, the incentives are being contorted. In fact, GEIA only grants incentives in reference to applied research. Indeed, the researcher is being motivated to create patentable active ingredients which are necessary prerequisites for drugs. However, GEIA sets no incentive for basic research. No later than the economic paper by Holmström/Milgrom, the difficulties of such contorted incentives are being discussed intensively. ${ }^{15}$ The result of this discussion can be summarized as "What

\footnotetext{
${ }^{11}$ Compare the study of Christopher Leptien (1996), Incentives for Employed Inventors: An Empirical Analysis of the German Law for Employees' inventions, 25 R\&D Mgmt. 213 (1995), in which from a sample of 116 questioned industrial researchers, $29.6 \%$ belong to the chemical-pharmaceutical industry.

${ }^{12}$ The case of Kary Mullis, for instance, who invented as employed researcher of Cetus the polymerase chain-reaction (PCR), which is nowadays an indispensable technique for biomolecular laboratories. When Mullis left his employer Cetus in 1986, he received a compensation of $\$ 10,000$. Five years later, Swiss Roche paid Cetus $\$ 300$ Mio. for the licence on the Taq-patent. Mullis did not receive any payment from the licensing fees. For compensation practices in the US see Thomas R. Savitsky, Compensation for Employment Inventions, Journal of the Patent and Trademark Office Society 9 (1991), 645-679.

${ }^{13}$ Roland Kirstein and Birgit Will, Efficient Compensation for Employees' Inventions, European Journal of Law and Economics 21 (2006), 129-148.

${ }^{14}$ Compare Erich Staudt et al., Incentive Systems as an Instrument of Company Innovation Management: Results of an Empirical Investigation in the R\&D Sector, International Journal of Technology Management 6 (1991), 395-413.

${ }^{15}$ Compare Bengt Holmström and Paul Milgrom, Multitask Principal-Agent Analyses: Incentive Contracts, Asset Ownership and Job Design, Journal of Law, Economics and Organization 7 (1991), 24-52.
} 
you reward is what you get": If the incentives are perverse, the activity of the employee will be lopsided. In the case at hand, it is to be expected that the researcher will concentrate solely on applied research for which he can expect patentable output. Under these circumstances, basic research will be ignored as far as possible. Based on the economic agency-theory and Holmström/Milgrom, it is recommendable to reward such discoveries perhaps with a bonus for each article printed in accredited journals. Then, incentives will be set also for basic research. Furthermore, the advantage is the determination of the "value" of the basic research by a neutral authority; comparable to an arbitration board for disputable inventions. It can be said that the double-blind peer-review-method used in medical-scientific journals would grant a neutral evaluation. Furthermore, it could be differentiated between the specific reputations of the journal while the regularly established impact-factor, which states how often the article was cited on an average, is added into the calculation of the compensation for the publication. Impartially, identifying the beneficiaries also helps to distribute the compensation for publication. Thus, the authors of a publication will receive compensation in the same way patent holders are receiving their reward. The regulations in regard to GEIA's compensation for co-inventors can be applied correspondingly. The so-called Vancouver-Group has established guidelines and criteria as to who has to be considered an author.

\subsection{Ascertainment of the compensation function}

Furthermore, the tie-up of the compensation to the revenues, as required by GEIA, combined with the risk aversion of the researcher may lead to a preference of low risk research projects. Therefore, these projects have a high possibility of being completed successfully. This is neither in the interest of the company nor in the general public's interest. In the case of GEIA, this means that due to the research project the augmentation of the enterprise's current market value is supposed to be the assessment base for the researcher's compensation. Unfortunately, the assessment base cannot be measured independently. After all, there are many different factors that influence the market value. But, how is the specific influence of one single project to be measured? This problem could be avoided by granting stock options to the researchers in charge. The reference date of the ex ante-market value is for inventions the application for a patent and for discoveries the submission for publication. The inventor should be able to exert his option for a specific length of time only after the drug was brought on the market or if the project was terminated prematurely at the time of announcement. Due to the fact that the results are going to influence the market value for a long time, the researcher should be granted a timeframe for the exertion of this option which is moved further into the future. ${ }^{16}$

At least in the area of pharmaceutical research, being compensated with stock options is appealing because even in a large company the invention of an innovative

\footnotetext{
${ }^{16}$ The further definition of this option is not the matter at hand in this paper.
} 
active ingredient influences clearly the market value. Compared with this, external effects like profiting from different factors of influence are very slight. Furthermore, the model could be based on GEIA, which would determine the scope of the granted share options. Besides, the regulations concerning the co-inventor's share and the participation factor could be applied. No matter what kind of compensation is being granted, it definitely is more preferable to tie it to the market value instead of the revenues.

\section{License contracts for external research}

A further shortcoming of GEIA is that it only provides incentives for employed researches. In today's business it is quite usual to work with freelancers or small specialist companies. In order to complement GEIA, incentives should also be set for license contracts, although the provisions in license contracts are a matter of contractual freedom.

\subsection{Importance of license contracts}

Pharmaceutical companies do not always succeed in developing new patentprotected substances for running out patent protection in time. Usually, it is tried to fill out these research gaps by licensing substances invented by smaller companies such as biotech companies, which do not have the financial resources for gaining the marketing authorization. ${ }^{17}$ The pharmaceutical company as licensee completes the development of this active substance by accomplishing the preclinical and clinical studies necessary for the marketing authorization. This way of external knowledge acquisition can be economical, and lowers, in particular, own expenditures as well as it helps to overcome existing internally capacity bottlenecks. However, special threats consist in the imperfect transfer of knowledge and know-how from the licensor to the licensee. In case of the pharmaceutical industry the direct disadvantage from the use of the substance by other companies may, indeed, be limited through patent protection, which secures the exclusive use of the underlying active substance. However, the Biotech enterprise usually has as a licenser additional know-how and experiences, which it won with the invention of the active substance. Thus, the pharmaceutical enterprise carries an indirect disadvantage, since the knowledge in a license agreement, which can be transferred, can be specified only incompletely.

In economic analyses a single payment is, often, regarded as an optimal license agreement. ${ }^{18}$ The reason for that is that a participation of the licensor in the sales of

\footnotetext{
${ }^{17}$ Compare Morton I. Kamien and Yair Tauman, Fees versus Royalties and the Private Value of a Patent, Quarterly Journal of Economics, 101 (1986), 471-491.

${ }^{18}$ Compare Inés Macho-Stadler and David J. Pérez-Castrillo, Contrats de Licences et asymétrie d'information, Annales d'Economie et de Statistique, 24 (1991), 190-191.
} 
the licensee is not incentive compatible, since the licensor has, at this time, no influence on the sales of the licensee. With license agreements between biotech and pharmaceutical companies it can be observed, however, mainly contracts, which provide high turnover-dependent royalty payments. A possible explanation for this observation is the ex post information asymmetry regarding a contractually agreed upon transfer of know-how. If the know-how transfer for the licensor is costly, it is subject to moral hazard, since the transferable know-how cannot be sufficiently contractually specified ex ante and the know-how transfer is itself not observable for third parties. Therefore, the licensor can assure a know-how transfer in the license agreement; this agreement is, however, not convincingly, as long as it is ex post not longer favourable for the licensor, to transfer know-how.

\subsection{Incentive problems}

In most cases, it is assumed that a biotech company has developed and patented an active substance, which presents itself as basis for the development of a drug in a specific indication. Since this enterprise possesses neither the capital nor resources for the execution of the necessary preclinical and clinical studies, it offers a license agreement, which grants the licensee the exclusive right to develop and market the resulting drug. Due to the disclosure obligation of the patentee, the biochemical characteristics of the patented active substance are observable and verifiable. Furthermore, in the license agreement can be stated that the licensor transfers a detailed documentation to the licensee. However, the licensor has acquired different kinds of technological knowledge regarding the active substance, which can be defined on the basis the criteria transferability and exclusiveness (see Table 1). Pivotal contents of the license agreement are the patented knowledge, as it is documented in the patent specification. Beyond that, the licensor, however, still has transferable, but not patentable knowledge (know-how) as well as non-transferable knowledge (tacit knowledge).

With these license agreements, frequently, a detailed documentation of the transferable know-how is agreed upon. However, the transfer is neither observable nor verifiable, since its 'contents' is not known to the licensee. For example, with biotechnological active substances, the scaling of the production procedures of small doses for the purposes of the preclinical laboratory tests to its industrial production represents a typical problem. A know-how transfer can help to reduce the necessary process steps in production and to thus lower the extra costs. ${ }^{19}$

\subsection{Characteristics of an optimal license agreement}

In order to find an optimal license agreement, one has to classify the actions of the two parties into four steps. Firstly, the licensor sketches the license agreement

\footnotetext{
${ }^{19}$ Compare Gary P. Pisano, The Development Factory: Unlocking the Potential of Process Innovation, Lessons from Pharmaceuticals and Biotechnology, Boston (1997), 210-227.
} 
Table 1

Different types of knowledge

\begin{tabular}{lll}
\hline & Non-transferability & Transferability \\
\hline Non-exclusiveness & - & not patentable knowledge (know-how) \\
Exclusiveness & tacit knowledge & patentable knowledge \\
\hline
\end{tabular}

and, thereby, implicitly decides on the transfer of know-how. The resulting draft is offered to the licensee, which will decide on acceptance and/or refusal ('take it or leave it'). Subsequently, the licensor transfers the patent including to the scientific documentation as well as the not observable and/or verifiable know-how. Lastly, the licensee produces the drug.

For the solution, in economic terms a perfect equilibrium has to be found by backwards integration, i.e. the entire play and each step must represent equilibrium. ${ }^{20}$ Thus, it is optimal for no contracting party to deviate from the specified strategy. It can be shown that the optimal license agreement must provide turnover-dependent royalty payments so that intended know-how transfer is credible. The license fee, i.e. the amount of the participation of the licensor in sales, is higher the higher the costs of the know-how transfer and lower the higher the value of the know-how. Hence, the incentive for the licensor for transferring know-how is smaller, the transfer costs are the higher and the value of the know-how for the pharmaceutical enterprise is the smaller.

The sketched analysis can provide a reason for the frequent royalty payments, which are to be observed with the development of biotechnological active substances since beginning of the 1990's. For example, Bristol-Myers Squibb acquired for 2bn Dollar the license for an active substance against cancer $\left(\right.$ Erbitux $\left.^{21}\right)$, which was developed by Imclone. This royalty payment was agreed as follows: Bristol-Myers Squibb acquired a 20\% stake in Imclone for $1 \mathrm{bn}$ Dollar and agreed upon the payment of the second billion in three further rates with separate milestones. Further, Imclone receives royalty payments at $39 \%$ of net proceeds of Bristol-Myers Squibb with Erbitux in the USA and Canada as well as at $50 \%$ of the result of the usual business activity in Japan.

\section{Conclusion}

GEIA represents a legal regulation for inventor's reimbursement which is questionable in regard to the augmentation of innovations made by German enterprises. On one side, there are no sufficient financial incentives for employees to exert themselves for employers' innovations. On the other side, there is the risk of perverse

\footnotetext{
${ }^{20}$ Compare Martin Osborne and Ariel Rubinstein, A Course in Game Theory, Cambridge (1994), 97.

${ }^{21}$ Bristol-Myers Squibb lost shortly before the patent protection for its best-selling cancer medicine Taxol (Paclitaxel) as well as for the diabetes medicine Glucophage. At the same time the company could not develop new substances in oncology.
} 
incentives because employees will not be influenced by economic advantages for the employer but solely by the amount of the anticipated reimbursement. It is questionable, given the current arrangement of reimbursement, if such payment policies are also considered appropriate by the employer.

Perverse incentives can result from the restriction to patentable innovations or technical ideas for improvement, because the essential basic research much-needed by enterprises in research-intensive branches is not at all being accounted for. In pharmaceutical industry, this can lead on one hand to very little employees' motivation for such research activities which results in the enterprise's loss of the up-todate knowledge of biomedical research. On the other hand, this can lead to conflicts among the different research teams, if only the patent holder receives a reimbursement but neither the researcher who did the preliminary work nor the researcher who followed a different approach. In this case, especially employees working in the field of cross-sectional technologies are discriminated. For example, a genome researcher cannot register her factual research results as a patent. But a researcher, who uses these insights to develop an active component, mustn't fear any restricted patentability.

Therefore, it is necessary to encourage not only the employees' applied research, but to increase also their incentives for basic research. Reimbursements for achievements in basic research are also to be granted to avoid the employees' one-sided focus in applied research. As it was pointed out, a bonus for scientific publications has proven to be very effective. Such a right to reimbursement should also be legally founded. The government's justification, which contains as sole reference the enterprises' individual regulations, is not sufficient by the economic point of view because it would lead to suboptimal agreements due to the disturbed contractual parities.

An additional problem is caused by the assignation of the "appropriate" reimbursement according to the regulation of GEIA. If one considers the reimbursement's adequacy not only from the employees' point of view but also from the employer's, one will realize that de lege lata this condition is not being guaranteed. The right to an inventor's reimbursement should incur only through economical advantages for the employer and vice versa. Moreover, the employees are confronted by perverse incentives which can lead to the non observance of the employee's economic advantages while making their decisions. From an economic point of view, it is essential to abandon the factual commission of the employees' inventions for a share of the modified (project) success, because the sales volume is only one component of the employee's decision making. 